\title{
Growth temperature dependence of channel size of the major outer-membrane protein (OprF) in psychrotrophic Pseudomonas fluorescens strains
}

\author{
Emmanuelle Dé, ${ }^{1}$ Nicole Orange, ${ }^{2}$ Nathalie Saint, ${ }^{1} \dagger$ Josette Guérillon, ${ }^{2}$ \\ René De Mot $^{3}$ and Gérard Molle ${ }^{1}$
}

Author for correspondence: Gérard Molle. Tel : +3302351467 05. Fax : +330235146704.
e-mail: Gerard.Molle@univ-rouen.fr

1 Institut Fédératif de Recherche

Multidisciplinaire sur les Peptides, URA 500 CNRS,

Faculté des Sciences, 76821

Mont-Saint-Aignan, France

2 Laboratoire de

Microbiologie du Froid,

Evreux, France

3 F. A. Janssens Laboratory of Genetics, University of Leuven, Heverlee, Belgium

\begin{abstract}
The outer-membrane (OM) permeability of the psychrotrophic bacterium Pseudomonas fluorescens strain MF0 for the $\beta$-lactam mezlocillin is increased at the optimum growth temperature $\left(28^{\circ} \mathrm{C}\right)$ compared to low growth temperatures $\left(8^{\circ} \mathrm{C}\right)$. In an attempt to explain this phenomenon, OM protein content was studied in cultures grown at both temperatures. No significant difference in proportion or composition was found, suggesting that a change in the structure and function of porins could be responsible for the differential permeability. The major OM protein OprF of two psychrotrophic $P$. fluorescens strains, MFO and OE 28.3, was purified from cultures grown at $8^{\circ} \mathrm{C}$ and $28{ }^{\circ} \mathrm{C}$ in order to reincorporate them in solvent-free lipid bilayers. From cultures grown at the same temperature, OprF displayed very similar channel-forming properties for both strains. Decreasing the growth temperature induced a threefold reduction of the major conductance values (250-270 pS in $1 \mathrm{M} \mathrm{NaCl}$ for $28^{\circ} \mathrm{C}$ cultures and 80-90 pS in $1 \mathrm{M} \mathrm{NaCl}$ for $8{ }^{\circ} \mathrm{C}$ cultures). The trypsin digestion kinetics showed a very different reactivity for these porins between cultures grown at $8^{\circ} \mathrm{C}$ and $28^{\circ} \mathrm{C}$. This may indicate that the pore structure of OprF is modified depending on the growth temperature, as suggested by its functional behaviour.
\end{abstract}

Keywords: Pseudomonas fluorescens, OprF, channel-forming properties, psychrotrophy, porins

\section{INTRODUCTION}

The intrinsic antibiotic resistance of Gram-negative bacteria may be explained in several ways. First, it is well known that the outer membrane (OM) of the cell acts as a permeability barrier for hydrophilic solutes (Nikaido \& Vaara, 1985). The passive diffusion rate of molecules, mainly through the non-specific porins, depends on their hydrophobicity (Nikaido, 1985) and/or their size or physicochemical properties. Nevertheless the permeability of the Pseudomonas aeruginosa $\mathrm{OM}$ was shown to be 10 - to 100 -fold lower than that of the

\footnotetext{
†Present address: Department of Microbiology, Biozentrum, University
} of Basel, CH-4056 Basel, Switzerland.

Abbreviations: DPhPC, diphytanoylphosphatidylcholine; octyl-POE, octyl-polyoxyethylene; OM, outer membrane; TLCK, $N^{\alpha}-p$-tosyl-L-lysine chloromethyl ketone.
OM of Escherichia coli (Yoshimura \& Nikaido, 1982; Hancock, 1985). In the former genus, the size of the nonspecific porin channels seems to be conserved, especially for the major $O M$ protein. Indeed, this has been determined in planar lipid bilayers for the OprF of two Pseudomonas fluorescens strains, MF0 (isolated from raw milk) and OE 28.3 (isolated from soils) (Dé et al., 1995) and also for the OprF of $P$. aeruginosa (Saint et al., 1992). The resistance to antibiotics, mainly with regard to the $\beta$-lactam family, may also be the result of the induction of well-described enzymes, such as $\beta$ lactamases, which hydrolyse the drug (Davies, 1994). The resistance of the mesophilic bacterium $P$. aeruginosa to $\beta$-lactams is thought to result from a balance between the diffusion rate of the drug through the $\mathrm{OM}$ and the induction rate of the $\beta$-lactamases (Nikaido, 1989).

Studies on the antibiotic resistance of mesophilic bacteria are usually performed on strains that have been 
cultured at the optimal growth temperature. However, recent studies have suggested that the growth temperature of psychrotrophic bacteria seems to be correlated with a modulation of OM permeability and drug resistance. In the antarctic psychrotroph Pseudomonas syringae $\mathrm{Lz} 4 \mathrm{~W}$, for example, the lipopolysaccharide (LPS) is more phosphorylated at a higher growth temperature $\left(22^{\circ} \mathrm{C}\right)$ than at a lower growth temperature $\left(0^{\circ} \mathrm{C}\right)$, where the post-synthetic phosphorylation of LPS is low (Ray et al., 1994). Under the latter culture conditions, the strain was also shown to be more sensitive to EDTA and to cationic antibiotics. Another study was performed with the psychrotrophic bacterium P. fluorescens (Orange, 1994). In this case, a minimum threshold of antibiotic penetration is required to cause induction of $\beta$-lactamase synthesis. At the optimum growth temperature $\left(28^{\circ} \mathrm{C}\right)$, this threshold is easily reached by $\mathrm{OM}$ permeation, whereas at a low growth temperature $\left(8^{\circ} \mathrm{C}\right)$ the penetration rate of the $\beta$-lactam is not high enough to reach this limit. In this condition the bacterium is found to be significantly less resistant. In these examples, the growth temperature seems to regulate the penetration of the drug through the OM independently of a modification of lipids as described by Russell (1990) or Bhakoo \& Herbert (1980).

As the permeation of $\beta$-lactam through the OM of $P$. fluorescens strain MF0, and certainly through the nonspecific porins, seems to determine the induction of $\beta$ lactamase production in the periplasmic space (Orange, 1994), we were interested to study the major OM protein of this bacterium (and of a related strain, $\mathrm{OE}$ 28.3) previously described as OprF-like porin (Dé et al., 1995).

The results described here show that this OprF protein produced different channel sizes in single-channel conductance experiments when it was re-incorporated into planar lipid bilayers depending on whether it had been extracted from cultures grown at low or high temperatures.

\section{METHODS}

Bacterial strains and growth conditions. Pseudomonas fluorescens strains MF0 and OE 28.3 are psychrotrophic bacteria with an optimum growth temperature of $28^{\circ} \mathrm{C}$. The MF0 strain was grown in nutrient broth (Difco). Tryptic soy broth, a more convenient growth medium, was used for the $P$. fluorescens $\mathrm{OE} 28.3$ strain because this strain secretes an exopolysaccharide which interferes with $\mathrm{OM}$ extraction in nutrient broth. After vigorous shaking at $28^{\circ} \mathrm{C}$ overnight or at $8^{\circ} \mathrm{C}$ for $48 \mathrm{~h}$, cells were harvested in the late exponential phase by centrifugation at $8000 \mathrm{~g}$ for $10 \mathrm{~min}$ at $4{ }^{\circ} \mathrm{C}$.

Isolation of bacterial membranes. OMs were extracted by the spheroplast procedure (Mizuno \& Kageyama, 1978) for both strains at different growth temperatures. This procedure was modified by including a washing step with phosphate buffered saline, which allowed the elimination of exopolysaccharides surrounding the bacteria, to increase the extraction yield (unpublished data). Total protein content was determined by the bicinchoninic acid method (Pierce), and the protein composition of the OM fractions was analysed by SDS-PAGE in a $7 / 15 \%$ discontinuous gel system (Laemmli, 1970). The relative protein concentration of each band was estimated by densitometry at $590 \mathrm{~nm}$ after Coomassie blue staining (Shimadzu).

Purification of OprF proteins. Purification of the major OM protein OprF from $8^{\circ} \mathrm{C}$ cultures was carried out by preparative native-like electrophoresis and electroelution in octylpolyoxyethylene (octyl-POE) media $(0 \cdot 1 \%, \mathrm{w} / \mathrm{v}$, octyl-POE, $192 \mathrm{mM}$ glycine, $25 \mathrm{mM}$ Tris/ $\mathrm{HCl}$ ) as described by Dé et al. (1995). Electroelution of this protein requires particular care to preserve the protein integrity : the time of elution should be minimized $(6 \mathrm{~h})$ or the experiment should be carried out at low temperature $\left(4^{\circ} \mathrm{C}\right)$. Purity control was achieved by SDSPAGE with silver staining. Proteins purified in octyl-POE were analysed by two-dimensional PAGE as described by De Mot \& Vanderleyden (1989).

Reconstitution in planar lipid bilayers. Virtually solvent-free planar lipid bilayers were formed by the technique of Montal \& Muller (1972) by the apposition of two monolayers on a $100 \mu \mathrm{m}$ diameter hole in a thin Teflon film $(10 \mu \mathrm{m})$ pretreated with hexadecane/hexane $(1: 40, \mathrm{v} / \mathrm{v})$. Measurement compartments were glass cells. Membrane currents under applied voltage were measured using a BLM 120 amplifier (Biologic) and $\mathrm{Ag} / \mathrm{AgCl}$ electrodes. The current fluctuations were stored on a DTR 1202 (Biologic) and were transferred to a computer where different measurements (current, amplitude histogram) were performed using software from Intracell. A diphytanoylphosphatidylcholine (DPhPC, Avanti) solution in hexane $(0.5 \%, \mathrm{w} / \mathrm{v}, 10 \mu \mathrm{l})$ was used as lipid, the electrolyte solution was $1 \mathrm{M} \mathrm{NaCl}, 10 \mathrm{mM}$ Tris $/ \mathrm{HCl}(\mathrm{pH} 7 \cdot 4)$ and the bulk concentration of the re-incorporated proteins was about $10^{-9} \mathrm{M}$ or $10^{-8} \mathrm{M}$ for the selectivity experiments. These latter experiments needed installation of a $\mathrm{KCl}$ gradient through the lipid bilayer: from $0 \cdot 1 \mathrm{M} \mathrm{KCl}$ on the cis side to $1 \mathrm{M} \mathrm{KCl}$ on the trans side. The zero-current potential was corrected by deducting the asymmetric potential due to the $\mathrm{KCl}$ gradient.

Determination of $\mathrm{N}$-terminal amino acid sequence. $\mathrm{OM}$ fractions (MF0 strain) obtained from cultures grown at $8^{\circ} \mathrm{C}$ were subjected to SDS-PAGE ( $7 / 17 \%$ gel system) and then electrophoretically transferred onto a PVDF membrane (Immobilon, Millipore). The membrane was stained with $0 \cdot 1 \%$ $(\mathrm{w} / \mathrm{v})$ Amido Black in $45 \%(\mathrm{v} / \mathrm{v})$ methanol and $9 \%(\mathrm{v} / \mathrm{v})$ acetic acid and destained in water. The $\mathrm{N}$-terminal sequence was determined by Sanofi-Winthrop Company (Notre Dame de Bondeville, France) using the Edman degradation (471A Protein Sequencer, Applied Biosystems) from the band corresponding to the major protein $\left(M_{\mathrm{r}} 32000\right)$.

Western blotting and immunodetection. After SDS-PAGE, the polypeptides were transferred to nitrocellulose $(H$. Bond, $0.22 \mu \mathrm{m}$ pore size; Amersham) as described by Towbin et al. (1979). Immunodetections were carried out using specific monoclonal antibody (MA28B9) directed against the $P$. fluorescens OE 28.3 OprF, as described elsewhere (De Mot et al., 1994).

Trypsin digestion. Samples $\left(100 \mu \mathrm{g} \mathrm{ml}^{-1}\right)$ containing OprFs purified by the octyl-POE method, from cultures of $P$. fluorescens MF0 grown at $8{ }^{\circ} \mathrm{C}$ and $28^{\circ} \mathrm{C}$, were incubated with trypsin (Fluka) at $12 \mu \mathrm{g} \mathrm{ml}^{-1}$ at $37^{\circ} \mathrm{C}$ for $3 \mathrm{~h}$. Digestions were carried out simultaneously for both growth temperatures and stopped by addition of $0 \cdot 1 \mathrm{mM} N^{\alpha}$-p-tosyl-L-lysine chloromethyl ketone (TLCK) at different times ranging from 0 to $3 \mathrm{~h}$ (Shaw et al., 1965). The samples were analysed by SDS gel electrophoresis $(7 / 15 \%)$ and silver staining. 


\section{RESULTS}

\section{Comparison of OM proteins according to growth temperature}

Previous studies (Orange, 1994) suggested that permeation of the $\beta$-lactam mezlocillin through the OM of the psychrotrophic bacterium $P$. fluorescens MF0 was higher at $28{ }^{\circ} \mathrm{C}$ than at $8{ }^{\circ} \mathrm{C}$. In an attempt to address this question, the OM protein content was studied at the two growth temperatures.

OM proteins were extracted by the spheroplast method (Mizuno \& Kageyama, 1978) from cultures grown at $28^{\circ} \mathrm{C}$ or $8^{\circ} \mathrm{C}$ and separated by SDS-PAGE after heating (Fig. 1a, lanes 2 and 4) or without prior heating (Fig. 1a, lanes 1 and 3) at $100^{\circ} \mathrm{C}$ in SDS sample buffer. Heatmodified forms appeared, mainly for the major OM protein OprF, which was converted into a heatmodifiable form of $M_{\mathrm{r}} 37000$ (Dé et al., 1995). This behaviour is characteristic of monomeric porins like $P$. aeruginosa $\mathrm{OprF}$ and the OprFs of $P$. fluorescens MF0 and $P$. fluorescens OE 28.3. However, no significant quantitative differences were found after densitometric analysis of bands obtained from the two temperatures.

\section{Influence of growth temperature on $P$. fluorescens OprF}

Fluctuations of OM permeability depending on growth temperature in $P$. fluorescens can be explained neither by the appearance of a particular porin at $28{ }^{\circ} \mathrm{C}$ nor by a change in the relative proportion of proteins. This led us to study the possible change of function and/or structure of the major OM porin, i.e. OprF protein with $M_{\mathrm{r}} 32000$, depending on growth temperature.

Purification. OprF was extracted from cultures at $28{ }^{\circ} \mathrm{C}$ or $8^{\circ} \mathrm{C}$ and purified in octyl-POE as described elsewhere (Dé et al., 1995). However, the purification of the OprF produced at $8{ }^{\circ} \mathrm{C}$ needed particular attention (see Methods) to avoid proteolytic degradation. The electrophoretic analysis of the purified proteins showed that the growth temperature did not alter the mobility of the OprFs in the SDS-polyacrylamide gels (Fig. 1b) and that the proteins had a very similar behaviour after heating. Moreover two-dimensional electrophoresis of these OprFs allowed us to check the high purity of the samples and clearly showed the same isoelectric point for the purified proteins regardless of the growth temperature of $P$. fluorescens MF0 (data not shown).

Function. The purified proteins from P. fluorescens MF0 were re-incorporated in planar lipid bilayers at a concentration of $10^{-9} \mathrm{M}$ in the cis compartment of the measurement cell. Several single-channel experiments were carried out for the $28^{\circ} \mathrm{C}$ and $8{ }^{\circ} \mathrm{C}$ OprFs and allowed us to detect small increments of current after application of constant potential in DPhPC membranes (Figs 2a and 3a). OprF protein from cultures grown at $28^{\circ} \mathrm{C}$ gave a mean conductance value of $250 \mathrm{pS}$ in $1 \mathrm{M} \mathrm{NaCl}$ (Fig. 2b, associated amplitude histogram, see Dé et al., 1995), whereas the same experiments per-

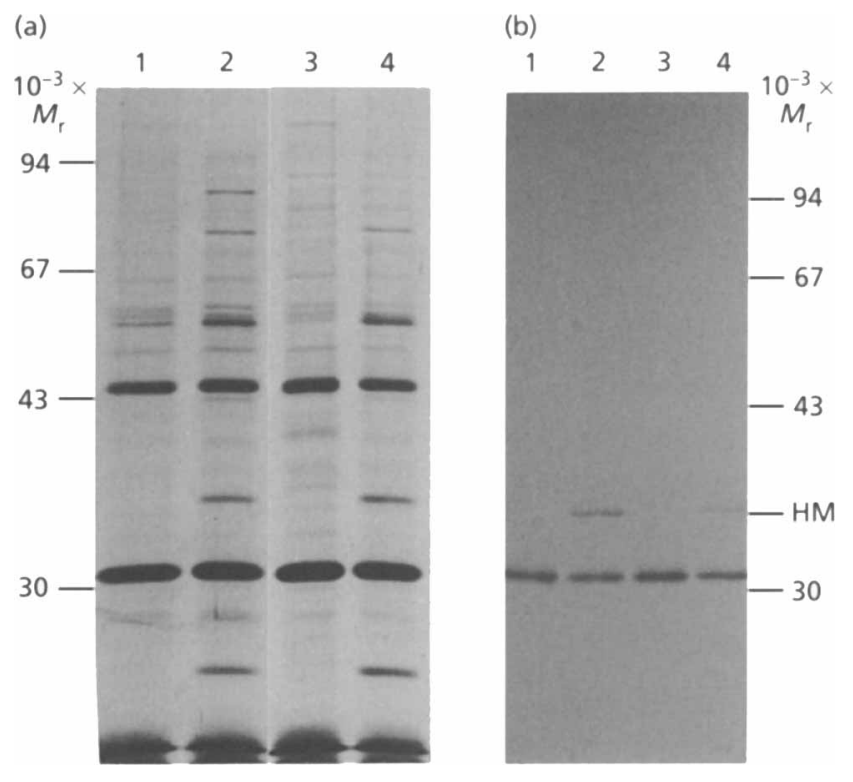

Fig. 1. (a) Comparison of OM proteins of $P$. fluorescens MFO grown at different temperatures by SDS-PAGE $(7 / 15 \%$ discontinuous gel system) with silver staining. OMs were isolated by the spheroplast method and solubilized in SDS buffer before loading. Lanes 1 and $2, \mathrm{OM}$ from $28^{\circ} \mathrm{C}$ culture; lanes 3 and $4, \mathrm{OM}$ from $8{ }^{\circ} \mathrm{C}$ culture. Lanes 1 and 3, OM without heating; lanes 2 and $4, \mathrm{OM}$ heated at $100^{\circ} \mathrm{C}$ for $10 \mathrm{~min}$. (b) SDS-PAGE (with silver staining) of OprF of the $P$. fluorescens MFO extracted from $28^{\circ} \mathrm{C}$ and $8{ }^{\circ} \mathrm{C}$ cultures purified by the octyl-POE method. The protein was heated at $100^{\circ} \mathrm{C}$ for $10 \mathrm{~min}$ to show the heat-modified form (HM). Lanes 1 and 2, OprF protein from $28^{\circ} \mathrm{C}$ culture; lanes 3 and 4 , OprF protein from $8^{\circ} \mathrm{C}$ culture. Lanes 1 and 3 , purified protein without heating; lanes 2 and 4, OprF heated.

formed for the $8^{\circ} \mathrm{C}$ OprF protein showed a considerably smaller major conductance value, $80 \mathrm{pS}$ in $1 \mathrm{M} \mathrm{NaCl}$ (Fig. 3b).

In order to verify whether this behaviour was specific to this particular $P$. fluorescens strain, the OprF was also purified from the psychrotrophic $P$. fluorescens strain OE 28.3 grown at different temperatures (De Mot \& Vanderleyden, 1991; De Mot et al., 1992, 1994; Dé et al., 1995). The re-incorporation of these OprFs was performed under the same experimental conditions. Discrete fluctuations of current were observed corresponding to a conductance value of $270 \mathrm{pS}$ for the $28^{\circ} \mathrm{C} \mathrm{OprF}$ protein and $90 \mathrm{pS}$ for the $8{ }^{\circ} \mathrm{C} \mathrm{OprF}$ in $1 \mathrm{M} \mathrm{NaCl}$ (Table 1 ). These results are in good agreement with the values for the MF0 strain described above.

The selectivity of these proteins was also investigated by using a gradient of $\mathrm{KCl}$ concentration $(0.1 \mathrm{M}: 1 \mathrm{M}$, cis:trans). For these experiments, protein concentration in the baths was tenfold higher than in single-channel measurements. After establishing the electrolyte gradient, a zero-current potential of $+20 \mathrm{mV}$ and $+18 \mathrm{mV}$ was found (after deducting the asymmetric potential) for the $8{ }^{\circ} \mathrm{C}$ protein from, respectively, strains MF0 and OE 28.3. According to the Goldman-Hodgkin-Katz 


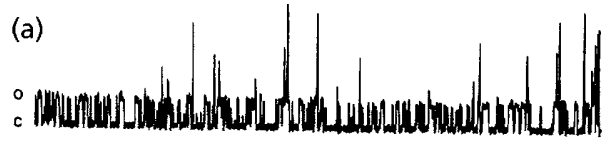

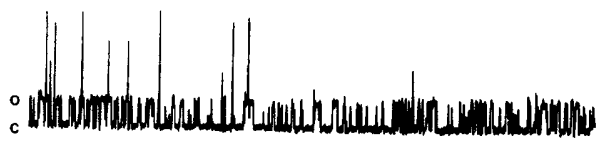

\rfloor$_{200 \mathrm{~ms}} 50 \mathrm{pA}$

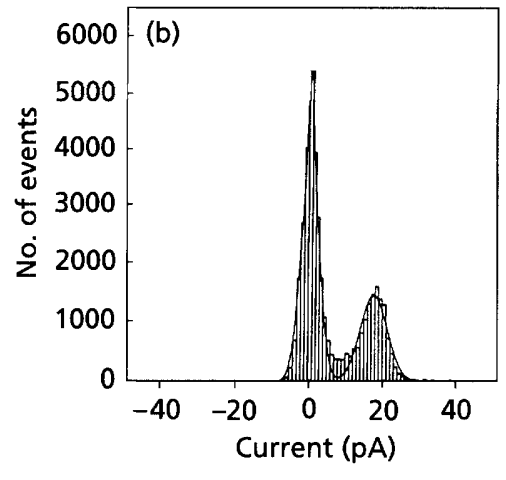

Fig. 2. Conductance of re-incorporated OprF protein purified from $P$. fluorescens MFO grown at $28^{\circ} \mathrm{C}$. (a) Trace of current fluctuations of the OprF protein $\left(10^{-9} \mathrm{M}\right)$ in a DPhPC membrane when the applied voltage was $70 \mathrm{mV}$. Electrolyte, $1 \mathrm{M} \mathrm{NaCl}$; digitization rate, $3000 \mathrm{~Hz}$; filter, $300 \mathrm{~Hz}$. o, open state; c, closed state. (b) Associated amplitude histogram with a Gaussian fitting which shows a conductance level of $250 \mathrm{pS}$. (a)

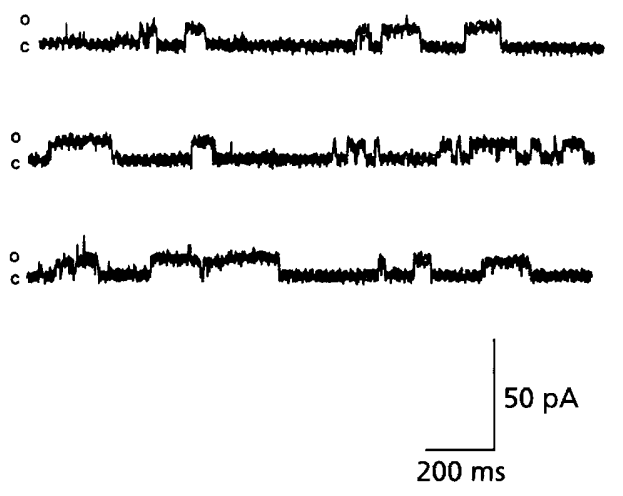

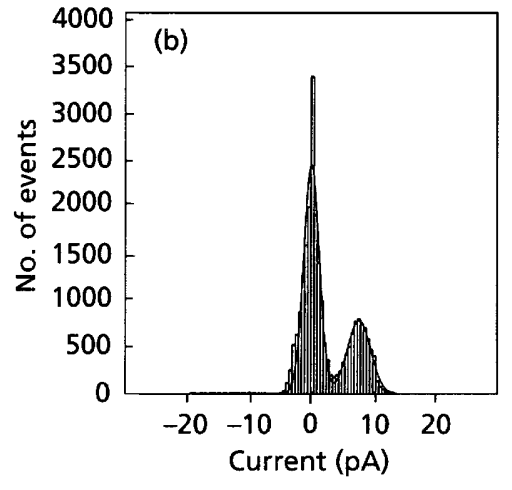

Fig. 3. Conductance of re-incorporated OprF protein purified from $P$. fluorescens MFO grown at $8^{\circ} \mathrm{C}$. (a) Single-channel current records of the OprF protein $\left(10^{-9} \mathrm{M}\right)$ in $1 \mathrm{M} \mathrm{NaCl}$, under a $-110 \mathrm{mV}$ potential. Digitization rate, $3000 \mathrm{~Hz}$; filter, $300 \mathrm{~Hz}$. o, open state; c, closed state. (b) Associated amplitude histogram with a Gaussian fitting which shows a conductance level of $80 \mathrm{ps}$.

Table 1. Single-channel conductance and selectivity values for the OprF proteins purified from $P$. fluorescens strains MF0 and OE 28.3 grown at $28{ }^{\circ} \mathrm{C}$ and $8{ }^{\circ} \mathrm{C}$

Values of conductance are given for OprF reincorporation in a DPhP membrane bathed by $1 \mathrm{M} \mathrm{NaCl}$. Selectivity ratios are calculated for an electrolyte gradient of $\mathrm{KCl}$ of $0 \cdot 1 \mathrm{M}: 1 \mathrm{M}$ (cis:trans).

\begin{tabular}{|cccccc|}
\hline Strain & \multicolumn{2}{c}{ Culture at $28{ }^{\circ} \mathrm{C}$} & & \multicolumn{2}{c|}{ Culture at $\mathbf{8}^{\circ} \mathrm{C}$} \\
\cline { 2 - 3 } \cline { 5 - 6 } & $\begin{array}{c}\text { Single-channel } \\
\text { conductance }(\mathrm{pS})\end{array}$ & $\begin{array}{c}\text { Selectivity } \\
\boldsymbol{P}_{\mathrm{K}} / \boldsymbol{P}_{\mathrm{Cl}}\end{array}$ & & $\begin{array}{c}\text { Single-channel } \\
\text { conductance }(\mathrm{pS})\end{array}$ & $\begin{array}{c}\text { Selectivity } \\
\boldsymbol{P}_{\mathrm{K}} / \boldsymbol{P}_{\mathrm{Cl}}\end{array}$ \\
\hline P. fluorescens $\mathrm{MF0}$ & $250 \pm 7$ & $1 \cdot 7$ & & $80 \pm 3$ & $2 \cdot 8$ \\
P. fluorescens $\mathrm{OE} 28.3$ & $270 \pm 7$ & $1 \cdot 4$ & & $90 \pm 3$ & $2 \cdot 5$ \\
\hline
\end{tabular}

equation (Hille, 1984), the $P_{\mathrm{K}} / P_{\mathrm{Cl}}$ ratio values $2 \cdot 8$ and $2 \cdot 5$ indicate a cationic selectivity. These values show a higher cationic selectivity than those determined by Dé et al. (1995) for the $28^{\circ} \mathrm{C}$ protein (Table 1). It is noteworthy that these values (from $28^{\circ} \mathrm{C}$ or $8{ }^{\circ} \mathrm{C} \mathrm{OprF}$ proteins) are close to the selectivity ratio $P_{\mathrm{K}} / P_{\mathrm{Cl}}=2$ found by Hancock (1986) for OprF from P. aeruginosa grown at $37^{\circ} \mathrm{C}$.

These single-channel results show a functional change in the channel size of the major OM porin depending on the growth temperature. Several hypotheses can be proposed to explain this behaviour and in particular temperature-dependent modifications of the structure of OprF porins.

Structure. The primary structure of the OprFs extracted from P. fluorescens MF0 grown at high or low temperature was compared after the analysis of the $\mathrm{N}$ terminal amino acid sequence. This sequence, QGQGAVEGELFYKKQYNDTV, was identical for both proteins. Using PCR amplification and Southern hybridization, a single oprF gene was identified in $P$. fluorescens strains MF0 and OE 28.3. This result rules out the possibility that two oprF genes could be present and expressed differentially according to the growth 


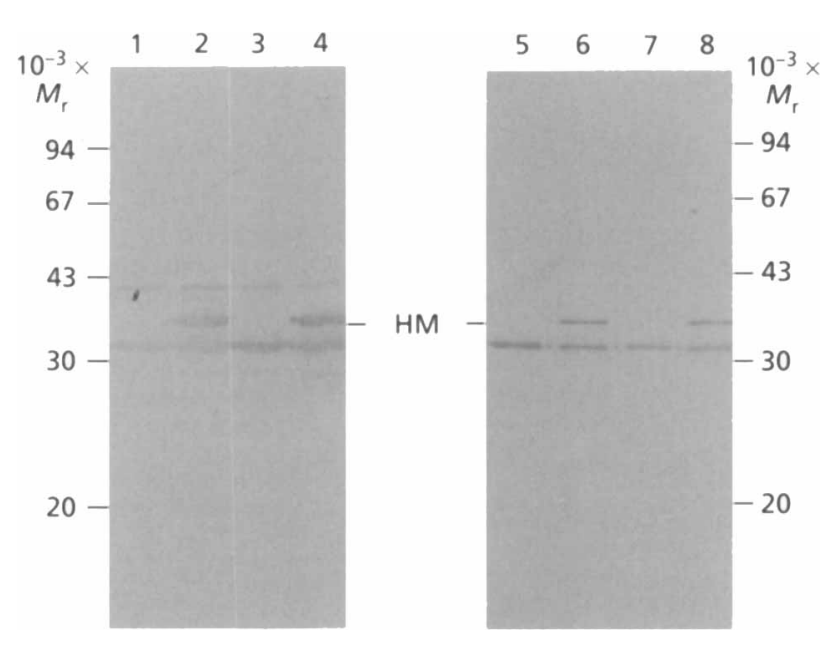

Fig. 4. Reactivity of monoclonal antibody MA28B9 with OprF from $P$. fluorescens MF0 depending on the growth temperature. Some samples of $\mathrm{OM}$ extracts and purified OprF proteins were heated at $100^{\circ} \mathrm{C}$ for $10 \mathrm{~min}$ ( $\mathrm{HM}$, heat-modified form). Lanes 1-4, OM extracted from cultures at $28^{\circ} \mathrm{C}$ (lanes 1 and 2) and $8{ }^{\circ} \mathrm{C}$ (lanes 3 and 4); lanes 5-8, purified OprF proteins from cultures at $28^{\circ} \mathrm{C}$ (lanes 5 and 6) and $8{ }^{\circ} \mathrm{C}$ (lanes 7 and 8). Lanes 1 and 3, OMs non-heated; lanes 2 and 4, OMs heated; lanes 5 and 7, OprFs non-heated; lanes 6 and 8, OprFs heated.

temperature. The oprF gene of both strains has been sequenced previously (De Mot et al., 1994; Dé et al., 1995 ) and showed a strong homology (94\% identity) between the deduced amino acid sequences of the two OprF proteins. The high homology between the two OprF proteins allowed us to use a monoclonal antibody (MA28B9) against the OprF of P. fluorescens OE 28.3 (De Mot et al., 1994) and to compare its reactivity with the OprF of strain MF0 produced at the two temperatures. Fig. 4 shows the reactivity of the P. fluorescens MF0 OM extracted from $28^{\circ} \mathrm{C}$ and $8^{\circ} \mathrm{C}$ cultures (lanes 1-4) after SDS-PAGE and electrotransfer onto nitrocellulose membrane and the reactivity of the purified proteins (lanes 5-8). After immunodetection, no difference was found between these samples, showing that the epitope was conserved.

Progress of proteolytic degradation by trypsin of OprFs purified from $8{ }^{\circ} \mathrm{C}$ and $28^{\circ} \mathrm{C}$ cultures of $P$. fluorescens MF0 was followed by SDS-PAGE (Fig. 5a, b). Timedependent sampling ( $3 \mathrm{~min}, 0.5 \mathrm{~h}, 1 \mathrm{~h}, 1.5 \mathrm{~h}, 2 \mathrm{~h}, 2.5 \mathrm{~h}$, $3 \mathrm{~h}$ ) was performed simultaneously for both proteins. After $3 \mathrm{~min}$ incubation (Fig. 5, lane 4) trypsin digestion seemed to generate the same proteolytic fragment of $M_{\mathrm{r}} 28000$ for both porins. It is noteworthy that the disappearance of $\mathrm{OprF}$ purified from the $8^{\circ} \mathrm{C}$ culture occurred more rapidly than for the $28^{\circ} \mathrm{C}$ preparation: after $1 \mathrm{~h}$ (Fig. 5 , lane 6 ) the $8^{\circ} \mathrm{C}$ porin had completely disappeared, whereas the $28^{\circ} \mathrm{C}$ one still remained after $2.5 \mathrm{~h}$ incubation (Fig. 5, lane 9). Cleavage sites for trypsin seem to be less accessible for the $28{ }^{\circ} \mathrm{C}$ OprF, suggesting a difference of tertiary structure between the $8^{\circ} \mathrm{C}$ and $28^{\circ} \mathrm{C}$ major $\mathrm{OM}$ proteins.

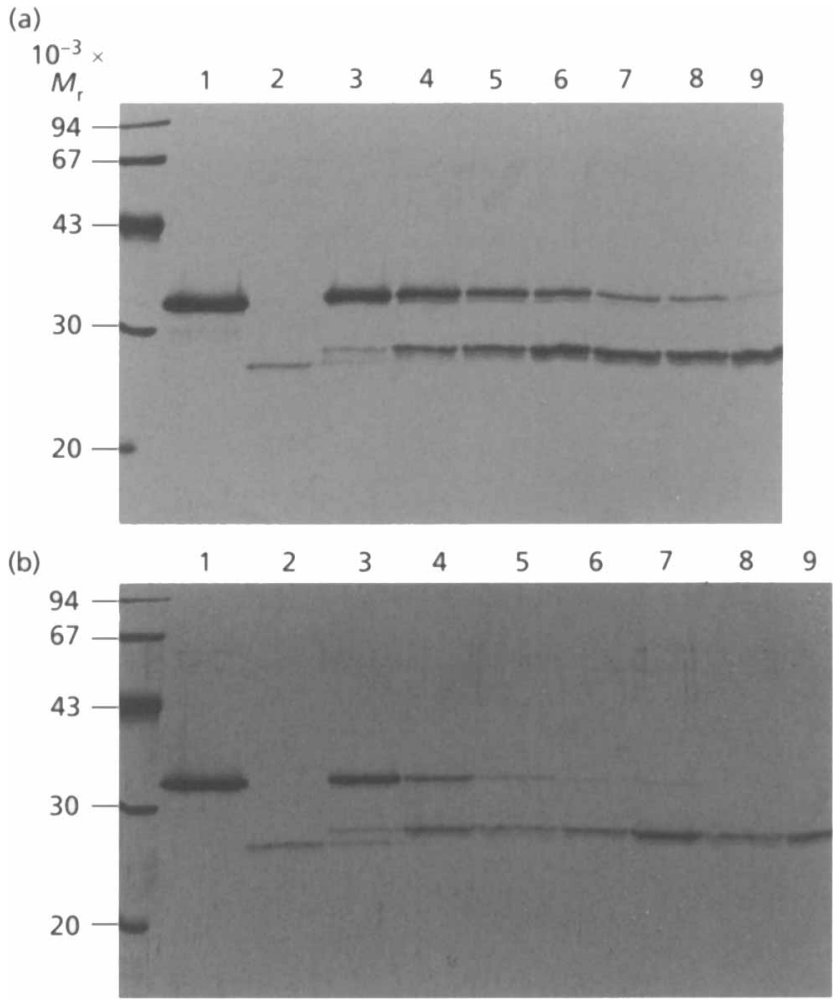

Fig. 5. Trypsin digestion kinetics of OprF from $P$. fluorescens MFO depending on the growth temperature. SDS-PAGE $(7 / 15 \%)$ of samples was carried out after the addition of TLCK to stop the digestion. (a) Trypsin digestion of OprF purified from a $28^{\circ} \mathrm{C}$ culture. (b) Trypsin digestion of OprF purified from an $8{ }^{\circ} \mathrm{C}$ culture. Lane 1, purified OprF; lane 2, trypsin; lane 3, after incubation for $3 \mathrm{~min}$; lane 4 , after $0.5 \mathrm{~h}$; lane 5 , after $1 \mathrm{~h}$; lane 6 , after $1.5 \mathrm{~h}$; lane 7 , after $2 \mathrm{~h}$; lane 8 , after $2.5 \mathrm{~h}$; lane 9 , after $3 \mathrm{~h}$.

\section{DISCUSSION}

Previous studies have shown that the psychrotrophic bacterium $P$. fluorescens MFO is more sensitive to the $\beta$ lactam mezlocillin at $8{ }^{\circ} \mathrm{C}$ than at higher growth temperatures. This difference seems to originate from a modification of the OM permeability depending on the growth temperature and in particular an increasing permeability allowing induction of $\beta$-lactamase synthesis at high growth temperatures (Orange, 1994).

Some authors have described the effects of temperature on bacterial OM proteins. An effect of the growth temperature on E. coli OM proteins was studied by Lugtenberg et al. (1976). They showed that the quantity of osmoregulated $\mathrm{OmpC}$ porin increased with increasing growth temperature concomitant with a decrease in the amount of the $\mathrm{OmpF}$ porin. Few studies are available on the effect of growth temperature on Pseudomonas aeruginosa OM proteins. Kropinski et al. (1987) observed some modifications of the OM protein profiles: at low growth temperatures there was an increase in a polypeptide with $M_{\mathrm{r}} 43000$ and a decrease in the content of $M_{\mathrm{r}} 21000$ (protein $\mathrm{H}_{1}$ ) and $M_{\mathrm{r}} 27500$ proteins. 
However, these data concern mesophilic bacteria and only few data are given for psychrotrophic bacteria. Our experiments show that these variations in the composition and the relative proportion of OM proteins are not observed for P. fluorescens.

The major OM porin, the OprF-like protein (Dé et al., 1995), was also studied. It could indeed be responsible, as in $P$. aeruginosa, for most of the non-specific OM permeability properties (Nicas \& Hancock, 1983). We demonstrated here that the conductance values of the channels formed by OprF extracted from cultures at the higher growth temperature $\left(250-270 \mathrm{pS}\right.$ at $\left.28^{\circ} \mathrm{C}\right)$ are about threefold higher than these obtained with a porin produced at low temperature $\left(80-90 \mathrm{pS}\right.$ at $\left.8^{\circ} \mathrm{C}\right)$. These results indicate that the pore size is larger for the $28^{\circ} \mathrm{C}$ OprF, which is compatible with previous studies on OM permeability (Orange, 1994). In other respects, the highest conductance values (for the $28^{\circ} \mathrm{C} \mathrm{OprF}$ ) determined in our results are in good agreement with the main value of $340-380 \mathrm{pS}$ (in $1 \mathrm{M} \mathrm{KCl}$ ) found for OprF from $P$. aeruginosa and also with the value clearly defined $(280 \mathrm{pS}$ in $1 \mathrm{M} \mathrm{KCl}$ ) for $P$. syringae $\mathrm{OprF}$ (Woodruff et al., 1986; Saint et al., 1992; Ullstrom et al., 1991). These low conductance values are not surprising in pseudomonads. Porins of $P$. aeruginosa, $\mathrm{OprE}_{1}$, OprC, $\mathrm{OprD}_{2}$, have also been shown (Yoshihara \& Nakae, 1989) to form small pores. OprE $\mathrm{O}_{1}$ shows single channel conductance of $230 \mathrm{pS}$ in $1 \mathrm{M} \mathrm{KCl}$ (from a culture of $P$. aeruginosa at $37^{\circ} \mathrm{C}$ ) and has no known substrate specificity (Obara \& Nakae, 1992). Conductance values for OprC are still not known, but it seems to form small non-specific channels (Nakae, 1995). Among these porins, only $\mathrm{OprD}_{2}$ is specific and is involved in the transport of basic amino acids (Trias $\&$ Nikaido, 1990). This protein is known to display two types of behaviour. Indeed it exhibits in DPhPC lipid bilayers a major closed state of the channel with conductivity of $30 \mathrm{pS}$ in $1 \mathrm{M} \mathrm{NaCl}$ and in DPhPC-LPS bilayers a major open state with conductance value of $400 \mathrm{pS}$ in $1 \mathrm{M} \mathrm{NaCl}$. This suggests that $\mathrm{OprD}_{2}$ behaves differently according to the presence or absence of LPS in bilayers. LPS could thus play a role in the regulation of the two states of the channel (Ishii \& Nakae, 1993). This particular variation in behaviour is observed for the optimal growth temperature in a mesophilic strain. On the other hand, in P. fluorescens psychrotrophic strains, the size of channels in OprF fluctuates with growth temperature, just as the phosphorylation state of LPS fluctuates in the psychrotrophic $P$. syringae (Ray et al., 1994). Structural modifications can be proposed to explain this functional change in the size of channels. Indeed the tertiary structure of these porins varies with the growth temperature, which is demonstrated here by a modification of accessibility of the cleavage sites to trypsin.

Such different states for the major OM porin OprF could explain the decreasing OM permeability at low temperatures already described (Orange, 1994). This particular behaviour of $P$. fluorescens MF0 can be related to the psychrotrophic nature of this bacterium, although there are similarities with the mesophilic bacterium E. coli. In $E$. coli the OM permeability is reduced when the environmental temperature increases, after human infection for example. Indeed the proportion of OmpC (smaller channel size) in the OM increases in relation to OmpF (larger channel size). This reaction protects $E$. coli against toxins (e.g. bile salts) which are found in the human digestive tract. The response of $P$. fluorescens MF0 to a temperature that falls under its optimum growth temperature could have a similar explanation. When $P$. fluorescens colonizes soil, water or plants it could decrease the OM permeability to avoid the entry of toxic molecules such as xenobiotics or toxins from plants. This effect is counterbalanced by the overproduction, at low temperature, of exocellular enzymes (lipases, proteases for example; Gügi et al., 1991) for degrading macromolecules into small units which provide $P$. fluorescens MF0 with carbon and energy sources.

The adaptation to environmental conditions which is described here for two major OM porins extracted from strains found in habitats as different as soil and milk could be a general feature of the OprFs from psychrotrophic $P$. fluorescens. While the behaviour of the minor porins in response to the growth temperature is still not known, their contribution to the phenomenon cannot be ruled out.

\section{ACKNOWLEDGEMENTS}

E.D. acknowledges the Conseil Régional de HauteNormandie for a doctoral fellowship. R.D.M. is a senior research associate with the national Fund of Scientific Research (Belgium). Part of this research was carried out in the framework of the EC Biotech BIO2-CT93-0196. This work was also supported by the GDR 1153 CNRS 'Peptides et Protéines Amphipatiques'. We thank Dr Pagès for his useful discussions and suggestions.

\section{REFERENCES}

Bhakoo, M. \& Herbert, R. A. (1980). Fatty acid and phospholipid composition of five psychrotrophic Pseudomonas spp. grown at different temperatures. Arch Microbiol 126, 51-55.

Davies, J. (1994). Inactivation of antibiotics and the dissemination of the resistance genes. Science 264, 375-382.

Dé, E., De Mot, R., Orange, N., Saint, N. \& Molle, G. (1995). Channel-forming properties and structural homology of major outer membrane proteins from Pseudomonas fluorescens MF0 and OE 28.3. FEMS Microbiol Lett 127, 267-272.

De Mot, R. \& Vanderleyden, J. (1989). Application of twodimensional protein analysis for strain finger printing and mutant analysis of Azospirillum species. Can J Microbiol 35, 960-967.

De Mot, R. \& Vanderleyden, J. (1991). Purification of a rootadhesive outer membrane protein of root-colonizing Pseudomonas fluorescens. FEMS Microbiol Lett 81, 323-328.

De Mot, R., Proost, P., Van Damme, J. \& Vanderleyden, J. (1992). Homology of a root adhesin of Pseudomonas fluorescens OE 28.3 with porin F of P. aeruginosa and P. syringae. Mol Gen Genet 231, 489-493.

De Mot, R., Schoofs, G., Roelandt, A., Declerck, P., Proost, P., Van Damme, J. \& Vanderleyden, J. (1994). Molecular characterization of the major outer membrane protein OprF from plant root- 
colonizing Pseudomonas fluorescens. Microbiology 140, 1377-1387.

Gügi, B., Orange, N., Hellio, F., Burini, J. F., Guillou, C., Leriche, F. \& Guespin-Michel, J. (1991). Effect of growth temperature on several exported enzyme activities in the psychrotrophic bacteria Pseudomonas fluorescens. J Bacteriol 173, 3014-3020.

Hancock, R. E. W. (1985). The Pseudomonas aeruginosa outer membrane permeability barrier and how to overcome it. Antibiot Chemother 36, 95-102.

Hancock, R. E. W. (1986). Model membrane studies of porin function. In Bacterial Outer Membranes as Model Systems, pp. 187-225. Edited by M. Inouye. New York: Interscience.

Hille, B. (1984). Selective permeability: independence. In Ionic Channels of Excitable Membranes, pp. 226-248. Sunderland, MA: Sinauer Associates.

Ishii, J. \& Nakae, T. (1993). Lipopolysaccharide promoted opening of the porin channel. FEBS Lett 320, 251-255.

Kropinski, A. M. B., Lewis, V. \& Berry, D. (1987). Effect of growth temperature on the lipids, outer membrane proteins, and lipopolysaccharides of Pseudomonas aeruginosa PAO. J Bacteriol 169, 1960-1966.

Laemmli, U. K. (1970). Cleavage of structural proteins during the assembly of the head of bacteriophage T4. Nature 227, 680-685.

Lugtenberg, B., Peters, R., Bernheimer, H. \& Berendsen, W. (1976). Influence of cultural conditions and mutations on the composition of the outer membrane proteins of Escherichia coli. Mol Gen Genet 147, 251-262.

Mizuno, T. \& Kageyama, M. (1978). Separation and characterization of the outer membrane of Pseudomonas aeruginosa. J Biochem 84, 179-191.

Montal, M. \& Muller, P. (1972). Formation of bimolecular membranes from monolayers and study of their properties. Proc Natl Acad Sci USA 69, 3561-3566.

Nakae, T. (1995). Role of membrane permeability in determining antibiotic resistance in Pseudomonas aeruginosa. Microbiol Immunol 39, 221-229.

Nicas, T. I. \& Hancock, R. E. W. (1983). Pseudomonas aeruginosa outer membrane permeability: isolation of a porin protein $\mathrm{F}$ deficient mutant. J Bacteriol 153, 281-285.

Nikaido, I. (1985). Role of permeability barriers in resistance to $\beta$ lactam antibiotics. Pharmacol Ther 27, 197-231.

Nikaido, I. (1989). Outer membrane barrier as a mechanism of antimicrobial resistance. Antimicrob Agents Chemother 33, 1831-1836.

Nikaido, I. \& Vaara, M. (1985). Molecular basis of bacterial outer membrane permeability. Microbiol Rev 49, 1-32.
Obara, M. \& Nakae, T. (1992). Porin of Pseudomonas aeruginosa forms low conductance ion channel in planar lipid bilayers. Biochem Biophys Res Commun 186, 645-651.

Orange, N. (1994). Growth temperature regulates the induction of $\beta$-lactamase in Pseudomonas fluorescens through modulation of the outer membrane permeation of a $\beta$-lactam-inducing antibiotic. Microbiology 140, 3125-3130.

Ray, M. K., Sehsu Kumar, G. \& Shivaji, S. (1994). Phosphorylation of lipopolysaccharides in the antarctic psychrotroph Pseudomonas syringae: a possible role in temperature adaptation. J Bacteriol 176, 4243-4249.

Russell, N. J. (1990). Cold adaptation of microorganisms. Philos Trans $R$ Soc Lond B Biol Sci 326, 595-611.

Saint, N., Orange, N. \& Molle, G. (1992). Conductance properties of protein $\mathrm{F}$ from Pseudomonas aeruginosa. Biophys J 61, A515, 2974.

Shaw, E., Mares-Guia, M. \& Cohen, W. (1965). Evidence for an active-center histidine in trypsin through use of a specific reagent. Biochemistry 4, 2219-2224.

Towbin, H., Staehelin, T. \& Gordon, J. (1979). Electrophoretic transfer of proteins from polyacrylamide gels to nitrocellulose sheets. Proc Natl Acad Sci USA 76, 4350-4354.

Trias, J. \& Nikaido, I. (1990). Outer membrane protein D2 catalyzes facilitated diffusion of carbapenems and penems through the outer membrane of Pseudomonas aeruginosa. Antimicrob Agents Chemother 34, 52-57.

Ullstrom, C. A., Siehnel, R., Woodruff, W., Steinbach, S. \& Hancock, R. E. W. (1991). Conservation of the gene for outer membrane protein OprF in the family Pseudomonadaceae: sequence of the Pseudomonas syringae OprF gene. J Bacteriol $173,768-775$.

Woodruff, W. A., Parr, T. R., Hancock, R. E. W., Hanne, L. F., Nicas, T. I. \& Iglewski, B. H. (1986). Expression in Escherichia coli and function of Pseudomonas aeruginosa outer membrane porin protein F. J Bacteriol 167, 473-479.

Yoshihara, E. \& Nakae, T. (1989). Identification of porins in the outer membrane of Pseudomonas aeruginosa that form small diffusion pores. J Biol Chem 264, 6297-6301.

Yoshimura, F. \& Nikaido, H. (1982). Permeability of Pseudomonas aeruginosa outer membrane to hydrophilic solutes. J Bacteriol $152,636-642$.

Received 12 September 1996; revised 31 October 1996; accepted 4 November 1996 